\title{
Choosing its own way: European cooperation in space. Europe as a third way between science's universalism and US hegemony?
}

\section{Lorenza SEBESTA}

Cooperation in science and technology is seldom recorded in historical accounts on European integration. ${ }^{1}$ Yet, collaboration was for European scientists, from early times, a favourite avenue of work and scientific achievement. It was not limited to international conferences and research groups, but formalized into international organizations, whose membership was restricted, most of the times, to Western European countries.

Space became the object of two organisations of this sort, the European Launcher Development Organisation (ELDO) and the European Space Research Organisation (ESRO) whose treaties were signed, respectively, in April 1962 (by Australia, Belgium, the Federal Republic of Germany, France, Great Britain, Italy and the Netherlands) and in June of the same year (by Belgium, Denmark, the Federal Republic of Germany, France, Great Britain, Italy, the Netherlands, Spain, Sweden and Switzerland, while Austria and Norway, initially, had observer status).

The case of space is especially intriguing because of the dual nature of its tools, launchers and satellites. With some technical adjustments, mostly of the re-entry vehicle and the guidance system, the technology embodied within a satellite launcher can be used for a missile carrying nuclear warheads. At the same time, satellites can host instruments devoted to scientific investigations as well as electronic devices to monitor, detect and locate objects and installations on earth for military purposes. Last but not least, scientific results obtained in some space fields, such as ionospheric studies, were crucial, for example, for engineers concerned with the construction of military missiles, whose reliability was dependant on a perfect knowledge of the medium in which they travelled and the condition of their re-entry into the atmosphere. ${ }^{2}$

The story of the birth of ELDO and ESRO reflects this peculiarity, intermingling scientific and technological aims with the political and military interests of the actors involved.

1. For some remarkable exceptions, see L. GUZZETTI, A Brief History of European Union Research Policy, European Commission, Luxembourg, 1995; F. PIGLIACELLI, Una comunità europea par la scienza: un ,sogno del saggi“?, PH.D Thesis, Pavia, 2004.

2. See for example, Archives Nationales, Paris, France, Mission recherche, Ministère de l'enseignement supérieur et de la recherche, 77/321. art. 442, Compte rendu. Comité de recherches spatiales, 05.03.1959 (serial numbers refer to the original deposit). 


\section{Space and Europe: a long-dated match}

The marriage between space and Europe has noble and time-honoured roots. In the mid $19^{\text {th }}$ century, while struggling to impose the idea of powered heavier-than-air flight instead of lighter-than- air machines (such as the then à la mode air balloons), Victor Hugo eloquently wrote in his epic poem La Légende des siècles:

"Cette nef magique et suprême [the aeroscaphe, precursor of the modern airplane], qui abolit les vielles règles, elle abaisse les monts, elle annule les tours; splendide, elle introduit les peuples, marcheurs lourds, dans la communion des aigles".

The favourite of Victor Hugo's communions, as is well known, was the "Etats-Unis d'Europe", which he was an early enthusiast of.

Space, as a physically dominant place, offered a good perspective to look at earth and wisely ponder over the artificiality of human-set frontiers. In line with the solid trust in the future which imbued Hugo's generation of French intellectuals and the prevailing attitudes of the "long peace century", the suppression of borders would automatically lead, for those inspired innovators, to a pacification of international society. This is why, in 1864, Félix Tournachon, alias Nadar, friend and admirer of Hugo, would write to him:

"Mettez l'homme en possession de l'atmosphère [et] le lien des ténèbres se défera de lui-même. Arminius a délivré Germania, Pélage l'Espagne, Wasa la Suède, Washington l'Amérique, Bolivar l'Amérique du Sud, Botzaris la Grèce, Garibaldi l'Italie. La Pologne en ce moment délivre la Pologne. Cela est grand et beau. Faisons plus, délivrons l'homme. De qui? De son tyran. La pesanteur [...].

Qu'es-ce que c'est que l'aéroscaphe dirigé? C'est la suppression immédiate, absolue, instantanée, universelle, partout à la fois, à jamais, de la frontière. [...] C'est l'évanouissement des armées, des chocs, des guerres, des exploitations, des asservissements, des haines. C'est la colossale révolution pacifique". ${ }^{4}$

Too good to be true. Nadar himself, in a mixed outburst of entrepreneurial and patriotic spirit, after becoming the first aerial reconnaissance photographer in history (on board his own air ballon, Géant), would participate in the defence of Paris in 1870-71, creating his own private company of aérostatiers. ${ }^{5}$ Among the tasks performed, Nadar would try to photograph Prussian troops from the sky.

The peculiar mixture of potential benefits of space for peace and war was, therefore, a well documented reality in European culture and practices when the

3. "Plein ciel" [1859], in: V. HUGO, La Légende des siècles, première partie: Vingtième siècle, E. Hugues Editeur, Paris, 1883.

4. Letter of Victor Hugo to Félix Nadar, January 1864, reproduced on the website membres.lycos.fr/ almasty/hugonad.htm. See also A. MATTELART, Histoire de l' utopie planétaire, la Découverte, Paris, 1999, p.169.

5. The first (public) compagnie d'aérostatiers militaires was created during the French Revolution, by the Comité de Salut Public, and later disbanded by Napoleon. See G. TISSANDIER, En ballon! Pendant le siège de Paris [1871] (rich in references to the first military uses of air balloons in France and in North America, the text is available as an ebook at www.gutenberg.org/files/11038/ 11038-h/11038-h.htm). 
first studies on rockets originated, in Russia. While Orville and Wilbur Wright were experiencing the thrill of the first flight by airplane at Kitty Hawk, New Carolina (1903), the Russian pioneer of space flight and visionnaire Constantine Tsiolkovsky (1857-1935) opened the avenues of interstellar flight with his momentous L'exploration de l'espace cosmique par le biais des moteurs à réaction (1903). Russian culture enriched these theoretical approaches with a messianic twist: Tsiolkovsky participated in that mystic movement known as "Russian cosmism", which characterized the country at the turn of the century. ${ }^{6}$ While amateur rocket societies flourished all over Europe, the idea of a messianic trip to the next world was re-cast in communist flavour by the writer Aleksej Tolstoj who, in his best seller Aelita (1922), sent his revolutionary character, Gusev, to the planet Mars along with his fellow traveller Los, engineer and dreamer. While Gusev was intent in raising the revolutionary spirit of the Red Planet's inhabitants against their dominant class, the sentimental Los became intrigued by the graces of the mysterious Aelita. Both attempts eventually failed and a precipitous return to earth of the two protagonists ended the book.

It is not by chance that the leaders of the Bolshevik revolution, according to whom socialism would equal "the power to the Soviets plus electrification", turned out to be great supporters of space research, intended as a powerful symbol of technological progress. In the 1920s and 1930s, laboratories and research groups flourished in Leningrad and Moscow. Silenced by Stalin's purges, the engineers attached to these early works would be the protagonists of Soviet space feasts after the Second World War.

Other countries came to perceive space as an arena of public policy much later. As a matter of fact, researches kept their amateur style even in the United States, where Robert Goddard, the great founding father of American space exploration, experimented with the first ever liquid-fuelled rocket (1926) at Auburn, Massachusetts, on his aunt's property.

Nazi Germany was, of course, the exception to this rule. In the 1930s, the work of Walter Dornberger and Werner von Braun (one of his youngest collaborators) in the field of missiles were recognised by the Wehrmacht as being a worthwhile financial and military bet. With a solid investment of money, human resources and "free" human (slave) labour, the rocket centre of Peenemünde managed to produce $3,200 \mathrm{~V}$-2s (Vergeltungswaffen ${ }^{7}$ ) in a very short time; so short that the war ended before all could be used, and they caused many more victims in their production phase, which took place in the Mittelbau-Dora concentration camp (part of the dreadful Buchenwald), than in their actual employment against Great Britain and Belgium. $^{8}$

6. A. TARASOV, L'espace et l'identité nationale russe, in: Hermès, L'espace, enjeux politiques, 34(2002), pp.79-91, spec. p.89.

7. Rataliatory arms.

8. M. NEUFELD, The Rocket and the Reich. Peenemünde and the coming of the ballistic missile era, The Free Press, New York, 1995, p.264. See also B. HARVEY, Europe's space programme. To Ariane and Beyond, Springer-Verlag, Berlin, 2003, pp.1-21. 


\section{Space scientists and the military after World War II}

In the first decade after the Second World War, European national institutions for science, like the Consiglio nazionale delle ricerche in Italy, were working hard to answer the most urgent and concrete needs of reconstruction. ${ }^{9}$ Few of them were involved in scientific fields of more long-term strategic value, such as the atomic programmes of France and Great Britain. In general, science and scientists did not stand high on the political agenda of continental countries at the time. This was even truer for new disciplines, such as space, which had difficulties to compete for resources with more well-established areas. Nor could much help be expected from industrialists either. Contacts between the two worlds, if ever experienced, remained rhapsodic and closely linked to personal ties. ${ }^{10}$ Satellites and their commercial exploitation represented, at the time, a far too unclear prospect of profit. At the same time, most short terms gains from space were thought to be in the realm of propulsion, rockets, guidance and control - which were the domain of the armed forces. It is not surprising, therefore, that the inception of scientific space activities after the World War II took place, for the most part, in Europe as in the United States, on the wings of the military. ${ }^{11}$

Even the most reluctant of scientists, like the Italian cosmic ray physicist Edoardo Amaldi, had to rely on them for logistics or resources or both. Others, such as the engineer Luigi Broglio, founder of the San Marco satellite project, served altogether as military official and used military premises and money for his scientific activities. ${ }^{12}$ French scientist Jacques Blamont, one of the pioneers of space science in France, found a key ally in general Robert Aubinière, who was director of the Centre Interarmées d'Essais d'Engins Spéciaux and of its launching pad of Colomb-Béchar, in Algeria, where the first upper atmosphere researches were performed by Blamont with Véronique sounding rockets in the second half of the 1950s.

Yet, Amaldi, one of the founding fathers of ESRO, maintained the position that it was "assolutamente essenziale" that any future organization be free from any linkage with the military. This did not mean, in the words of Amaldi, that the

9. L. GUZZETTI, L. SEBESTA, Gli aspetti internazionali dell'attività del CNR nel secondo dopoguerra, in: R. SIMILI, G. PAOLONI (eds.), Per una storia del Consiglio Nazionale delle Ricerche, Laterza, Roma-Bari, 2001.

10. F. PIGLIACELLI, Italy, Esro and Eldo, in: M. DE MARIA, L. ORLANDO (eds.), Italy in Space, vol.I, Looking for a strategy 1957-1975, ESA, Noordwijk, 2005. See also the interview of Luigi Broglio with L.Sebesta, 22 June 1992.

11. For the American case, see D. de VORKIN, Science with vengeance: how the military created the US space science after the World War II, Springer-Verlag, New York, 1992. Relations between the military and European space scientists have never been explored in comparative terms as such; for the Norwegian case, see O. WICKEN, Cold War in Space Research: Ionospheric Research and Military Communication in Norwegian Politics, in: J.P. COLLET (ed.), Making Sense of Space. The History of Norwegian Space Activities, Scandinavian University Press, Oslo, 1995, pp.41-73.

12. M. DE MARIA, From cosmic rays to the start of space research (1946-1958), in: M. DE MARIA, L. ORLANDO (eds.), op.cit. 
military could not benefit from the almost certain spill over from scientists' research. ${ }^{13}$ It just meant that, in order to have any hope of consolidating the newly-born discipline, scientists would not benefit from being too closely associated with the military in public minds. In the framework of the new democratic regimes, both public legitimation and political support would definitely be weakened by what was widely perceived as an altogether 'malevolent' connection between space research and the military - rooted as it was in fresh memories of the association between early missile development and the Nazis. "A purely scientific organization", Amaldi pondered in the paper that is now considered as the founding stone of ESRO, "would not only have immense moral authority, but it would, most probably, be the only kind of organization at present practicable in Europe, given that its constitution will have to be ratified by the Parliaments of the member countries". ${ }^{14}$

Physicists had been living with a similar problem since the bombing of Hiroshima and Nagasaki, when the practical results of their theories and discoveries had been put to fruition against Japanese citizens with appalling destructive consequences. While some of them, like Hans Bethe, Albert Einstein, Cecil Frank Powell, Eugene Rabinovitch and Joseph Rotblat would eventually join forces to struggle overtly for peace and disarmament, the most widespread attitude was to downplay their connections with the military.

Internationalisation seemed to offer a welcome way out from the moral dilemma of working with or/and for the military. Once the pioneer phase had come to an end, a too tight relation with the military could turn out to become not only a threat to freedom of research but, more seriously, a setback for the public legitimacy of an entire discipline.

\section{Sputnik and its immediate context}

Under the leadership of Lloyd Berkner, a highly reputed physicist and distinguished member of the US National Academy of Science, internationally coordinated plans for research activities using instrumented satellites were being discussed since 1950. In his capacity as executive secretary of the Joint Research and Development Board (JRDB) of the department of Defense, created in 1946 for reviewing all national military research and development, he was especially well placed to put this plan on its feet. "His interest in space", his biographer Newell states,

13. Archivio Amaldi, Università la Sapienza, Rome, Italy, box 212, Lettera Amaldi a Gino Crocco (Princeton), 16.12.1958.

14. HAEU [Historical Archives of the European Union], Fiesole, Italy, COPERS-1, Edoardo Amaldi, Space Research in Europe, 30.04.1959, reproduced in: N. TINJOD, B. BATTRICK, The Archives of the European Space Agency. A Snapshot, ESA, Noordwijk, 1998, pp.19-24, p.22 for the citation. 
"grew both out of his interest in geo-physics and out of his conviction that international science offered a potentially powerful (yet seriously neglected) vehicle for promoting American interests and values in the post-world war period“". ${ }^{15}$

After much international and national scientific and political lobbying, an institutional framework was finally set up in 1957, with the inauguration of the International Geophysical Year (IGY), due to commemorate the 25th anniversary of the second International Polar Year. The chosen period (1957-58) also reflected the search for a time of maximum solar sunspot activity, which greatly enhanced the interest of many of the researchers involved.

Held under the auspices of the Comité Spécial Année Géophysique Internationale (CSAGI) of the International Council of Scientific Unions (ICSU), after consultation between Berkner and representatives of the State Department, the IGY was opened to "all nations of the world, including those behind the iron curtain". ${ }^{16}$ It sponsored research from more than sixty countries, performed with space-based tools such as ballons, rockets and satellites, notably in the area of the physics of upper atmosphere, the earth's structure and shape, oceans and the Antarctic. ${ }^{17}$ The IGY was a very matter-of-fact cooperation and refrained from any form of centralised institutionalisation. It was, first of all, a means for coordinating national experiments and exchanging (limited) information on them. International cooperation within this framework meant, for example, the synchronization of the firing of sounding rockets for the study of upper atmosphere or the mutual tracking of satellite vehicles.

As a matter of fact, experiments were conducted by national scientific groups which retained full operational control of them, i.e. control over both their performance and results. The Soviet satellite Sputnik 1, conceived and set up within the framework of programme, was launched by a strictly national (and military) rocket, the $R$-7-originally, an intercontinental ballistic missile, able to reach American territory from the Soviet Union. The US's response, Explorer-1, was carried into orbit by a Jupiter-C, originally an Intermediate Range Ballistic Missile (IRBM) developed by the Army Ballistic Missile Agency of Huntsville, Alabhama, under the supervision of Werner von Braun. Both rockets were the results of the US-USSR race in the field of ballistic missiles. ${ }^{18}$

The launch of Sputkin 1 and, more convincingly, Sputnik 2, which carried a much heavier payload, brought to the fore the potential destabilizing effect of a Soviet lead in intercontinental missiles for the North Atlantic Alliance as it would create the basis

15. A.A. NEEDELL, Science, cold war and the American state. Lloyd V. Berkner and the balance of professional ideals, Harwood Academic Publishers, Amsterdam, 2000, p.298.

16. Ibid., p.329. Letter Berkner to Walter Rudolf (Department of State Science Advisor's Office), 16.03.1955.

17. R. BULKLEY, The Sputnik Crisis and Early United States Space Policy. A Critique of the Historiography of Space, Macmillan, London, 1991, spec. pp.87-122. A useful testimony by one of the most relevant actors (then in charge of NASA's international affairs) is: A. FRUTKIN, International Co-operation in Space, Prentice-Hall, Englewood Cliffs, pp.18-19.

18. A.J. LEVINE, The Missile Space Race, Praeger, Westport, 1994, pp.47-49. 
for the loss of invulnerability for the US and, therefore, weaken the credibility of the American nuclear deterrent for Europe. More broadly, Sputnik seemed to attest to the effectiveness of scientific and technological firsts as a propaganda tool and symbolic surrogate of political primacy. The advances of the Soviets in the field of scientific manpower began to be signalled as a serious political as well as military problem within NATO ${ }^{19}$ What if communism turned out to be the most efficient way not only to provide social justice, but to guarantee technological and scientific progress - a most cherished foundation for liberal democracies?

European space cooperation had much to do, directly or indirectly, with the efforts put in place to answer this outstanding challenge.

\section{Post Sputnik: a new centrality for missiles}

In May 1957, NATO had adopted the "massive retaliation" doctrine, by which nuclear arms would be used in Europe against any kind of military attack, whether conventional or nuclear. The effectiveness of this newly adopted doctrine, which had raised more than one criticism for the lack of political representation of European allies in decisions related with the use of nuclear devices, was linked to the credibility of American atomic deterrence. This would be severely weakened by any Soviet technical advance which opened American territory to direct retaliation from Moscow.

The Soviet missile which launched Sputnik into orbit was a modified intercontinental ballistic missile, whose first test had taken place in the summer of 1957: instead of taking a satellite to orbit, it could take a warhead to Washington. Which American president would dare to use atomic weapons for the defence of Europe, exposing its own population to the Armageddon of an atomic retaliation from Moscow? In order to dilute the destabilizing effect of this new strategic balance, the US was ready to offer a variegated menu of nuclear devices to their NATO allies. The creation of an American stockpile of atomic weapons in Europe ("which will be readily available for the defence of the Alliance in case of need") was to go hand in hand with the deployment of US IRBMs on European soil. Stringent conditions on their use were attached to both. A third proposal, related to the development of an "indigenous" European IRBM force set up with US technical help, seemed to offer a much more promising perspective of autonomy to allies.

The final communiqué of the NATO Council of December 1957 clearly stated that

"as regards defence production, we have decided, in view of the progress already made, to take further measures within NATO to promote the co-ordination of

19. J. KRIGE, NATO and the Strengthening of Western Science in the Post-Sputnik Era, in: Minerva: A Review of Science, Learning, and Policy, 1(2000), pp.81-108. 
research, development and manufacture of modern weapons including intermediate range ballistic missiles". ${ }^{20}$

One has to situate the American offer in the context of the mobile front of Europeans' own efforts to join forces in the fields of "advanced" armaments. ${ }^{21}$ In particular, ever since the Suez crises (1956), France and Great Britain had began a series of bilateral conversations on what both thought by that time as being the inevitable transition from interceptor fighters and strategic bombers to guided weapons. Early in 1957, the French minister of Defence, Maurice Bourges-Maunoury, had suggested to his British counterpart, Duncan Sandys, that, in this field, "the requirements might be studied in common and a selection made among the designs available in each country". ${ }^{22}$ A technical agreement on a guidance system, by far one of the hardest pieces of engineering in a missile, was signed later that year (agreement Crépin-Cockburn). ${ }^{23}$ At the same time, a controversial Franco-German-Italian preliminary agreement (F-I-G) was signed in November 1957, by which the three governments would stand ready to cooperate in the fields of nuclear energy ${ }^{24}$ aeronautics and missiles. ${ }^{25}$ It is not without interest to note that on the very premises of the NATO Council of December 1957, the French Prime minister Félix Galliard publicly announced the existence of F-I-G and invited other members to join in. ${ }^{26}$ Cooperation in the development and manufacture of IRBMs alluded to by the Americans could possibly be organized within its framework.

Great Britain had other plans: having developed since 1954 an autonomous IRBM, Blue Streak (under American licence), they thought that this could be the basis for a future European missile. The US, however, were non committal about UK willingness to begin technical discussions with France on Blue Streak as a basis for a future European missile; ${ }^{27}$ as a matter of fact, American secretary of Defense Neil McElroy seemed openly to prefer F-I-G as a way "to get the program

20. NATO Archives, Brussels, C-VR(57)82 (final), 24 February 1958, Verbatim Record meeting of the Council, 16.12.1957, Secret NATO. The quotes are from the official final Communiqué, NATO Council, 16-19.12.1957, Paris, in: Text of Final Communiqués, 1949-1974, NATO Information Service, Bruxelles, no date, pp.108-116.

21. M. O'DRISCOLL, 'Les Anglo-Saxons', F-I-G and the rival conceptions of 'advanced' armaments research and development co-operation in Western Europe, 1956-1958, in: Journal of European Integration History, 1(1998), pp.105-110.

22. Public Record Office (PRO), Kew, Richmond, Great Britain, DEFE 7/702, Extract from record of discussion between Bourges-Maunoury and Sandys, 14.02.1957 (secret).

23. S.M. DECUP, France-Angleterre. Les relations militaires de 1945 à 1962, Economica, Paris, 1998, pp.247-249.

24. Reference was made to the diffusion plant of Pierrelatte.

25. Documents Diplomatiques Français (DDF), 1957, vol.II, Imp. nationale, Paris, 1991, doc. n.380, Protocole entre le ministre de la Défense nationale et [...] les ministres de la défense de la République fédérale allemande et de la République italienne, 28.11.1957, pp.762-763. Among others, see L. NUTI, The F-I-G story revisited, in: Storia delle relazioni internazionali, 1(1998), pp.69-100.

26. DDF, 1957, vol.II, doc.452, De Croucy-Chanel (permanent representative to the NATO Council) to Pineau (minister for Foreign affairs), 18.12.1958. See also L.NUTI, op.cit., pp.77-78. 
[for European IRBMs]'off the ground"”, ${ }^{28}$ Creating from scratch a second generation of more reliable, solid-fuel, European missiles seemed, for a while, to be US preferred option. Or, at least, this is what French general Crépin, during a discussion held at the British ministry of Supply and Defence in April 1958, seemed to hint at when speaking about US willingness "to help both technically and financially" a collaborative project between France, the Federal Republic of Germany and Italy, aimed at building a "solid motor missile". ${ }^{29}$ As Lauris Norstad, Supreme Allied Commander Europe, recognized at the time, the US seemed to be "in a real box": with so many independent and un-related negotiations under way, and this new military urge, it would be difficult for the US to disillusion any of its allies. $^{30}$

The long term goals of US policy, however, made these auspices difficult to realize. The negotiations on the reduction and control of nuclear armaments with the Soviet Union seemed to be at the top of the agenda in the final years of Dwight D. Eisenhower's presidency. ${ }^{31}$ Were these efforts to become a reality, any autonomous production of "advanced weapons" in Europe would be seen as a disturbing element. ${ }^{32}$

On the contrary, the idea of a European collaboration on missiles appealed to French government. In February 1958, the Comité de Defense was ready to say that the force de frappe

"n'aura plus, sauf pendant la période intérimaire, le caractère purement national qui lui était jusqu'à maintenant demandé. Il est en effet admis que les études relatives à l'engin sol-sol pourront être faites dans un cadre interallié et qu'en attendant leur aboutissement la capacité de frappe sera fournie par les IRBM américains". 33

27. This explicit request was forwarded by the under secretary of the ministry of Defence to the British Joint Services Mission, Washington DC; PRO, DEFE 7/264, Wheeler to Pendlebury, 17.02.1958 (secret).

28. "Secretary McElroy reviewed his discussion with Strauss [German Defence minister] in reference to the F-I-G arrangement, which he believed was the best immediate method of getting the program 'off the ground"'; National Security Archives (NSA), US Nuclear History, Nuclear Arms and Politics in the Missile Age, 1955-1968, doc.1076, Office of the assistant secretary of Defence, Memorandum for the Record, Highlights of Meeting between secretary McElroy and general Norstad, 25.03.1958 (top secret).

29. PRO, DEFE 7/264, Note of a discussion with general Crépin, 30.04.1958.

30. NSA, US Nuclear History, Nuclear Arms and Politics in the Missile Age, 1955-68, doc.107, Meeting between Donald Quarles (deputy secretary of Defence) and Lauris Norstad (SACEUR), 18.01.1958.

31. The first steps of US nuclear arms control policy are analysed in M. GALA, Il paradosso nucleare. Il Limited Test Ban Treaty come primo passo verso la distensione, Polistampa, Firenze, 2002.

32. G.-H. SOUTOU, L'alliance incertaine: les rapports politico-stratégiques franco-allemandes, 1954-1996, Fayard, Paris, 1996, p.135; F. COSTIGLIOLA, France and the US: The Cold Alliance since World War II, Twayne's International History Series, New York, 1992, p.134.

33. Service historique de la Défense, Archives Armée de l'Air, Vincennes, France, E 1773, Comité de défense, 06.02.1958, Fiche relative à la question 1, Politique militaire à long terme et plan quadriennal, 1959-1962. 
This open-mindness in military affairs was not abandoned once Charles de Gaulle came to power. It is true that the F-I-G, Anglo-French and other international agreements were scrutinized. However, while the atomic section of F-I-G was soon dismissed ("nous ne devons pas poursuivre la collaboration dans le domaine atomique"), cooperation in both conventional areas and missiles was not discarded ("en matière d'IRBM nous ne devons pas rejeter l'idée d'une fabrication commune"). ${ }^{34}$

The British option remained on the table. Many in Great Britain thought that, as a consequence of the Soviet Sputnik, UK relations with the US in terms of military cooperation would be consolidated. ${ }^{35}$ Indeed, in October 1957, after meeting with Harold Macmillan, Eisenhower had requested the Congress to modify the MacMahon act, which had severely limited, since 1946, the possibility to share sensitive military secrets with other countries. ${ }^{36}$ Great Britain seemed to be best placed to work as a bridge between the US and Europe in terms of advanced technology. This was especially true in the field of both nuclear bombs and delivery vehicles. At the end of 1959, Macmillan seemed ready to offer informal British nuclear assistance to France, an idea which had been discretely advanced by the British ambassador to Paris, Gladwyn Webb. ${ }^{37}$ The suggestion of a common European strategic nuclear force, as a "complement" to the American Strategic Command, had been publicly aired some months before by the British delegation in the context of the Western European Union assembly, the only exclusively European forum devoted to defense - including Britain and continental European members as well. ${ }^{38}$

In 1959, de Gaulle began to understand that, despite the fin-de-non recevoir granted to his memorandum of September $1958,{ }^{39}$ the idea of a triumvirate within NATO was not dead, but needed some restyling.

34. Idem., Décisions de la réunion de défense nationale (extrait), 17.06.1958.

35. A. HORNE, Macmillan, 1957-1986, vol.II, Macmillan, London, 1989, p.53; J. BAYLIS, Anglo-American Defence Relations, 1939-1984, Macmillan, London, 1984, p.92; J. MELISSEN, The Politics of US Missile Deployment in Britain, 1955-1959, in: Storia delle relazioni internazionali, 1 (1998), pp.151-186, spec. pp.43-44. See also, M. De MARIA, Europe in space. Edoardo Amaldi and the Inception of ESRO, ESA HSR-5, ESA, Noordwijk, 1998.

36. The amendment, which came into force in June 1958, granted a lifting of the original restrictions for those countries which had already reached substantial progress in nuclear weapons. A minor revision had been already offered in 1954. Cf. J. BAYLIS, op.cit., p.71; J. MELISSEN, op.cit., p.25.

37. W. KAISER, Using Europe, Abusing the Europeans. Britain and European Integration, 1945-63, Macmillan, Houndmills, 1996, p.120; L. KAPLAN, Un point de vue américain sur de Gaulle et l'OTAN, in: De Gaulle et son siècle, vol.IV, op.cit., pp.321-332, spec. p.326.

38. N. SALTER, Is Defence the Entry Ticket?, in: Journal of Common Market Studies, 3(July 1963), pp.260-273.

39. M. VAÏSSE, La grandeur. Politique étrangère du général de Gaulle, 1958-1969, Fayard, Paris, 1998, pp.117-123. 


\section{The NATO option for space science cooperation discarded}

The launch of Sputnik brought to the forefront the problems related to the preparedness of the Atlantic alliance, not only in terms of hardware, but in terms of scientific manpower, with an emphasis on those sciences with more visible military spill-over. This was all the more so because technological advance had come to be signalled as a surrogate for political primacy. This challenge appeared to be as severe as the strictly military one. For a short time, NATO was thought to be a possible arena for Western response in this field. The same NATO council which discussed the nuclear consolidation of the organisation set out the basis for creating a Science Committee, "to speak authoritatively on science policy" and to ensure "the full development of our science and technology" which was deemed "essential to the culture, to the economic and to the political and military strength of the Atlantic community". Its first chairman was Norman Ramsey, professor of physics at Harvard University, eminent American nuclear physicist and, later, Nobel prize-winner. ${ }^{40}$

In January 1958, after the launch of Explorer 1, Eberhardt Rechtin, an engineer of the Explorer satellites series, then vice-president of the newly established Avionics Panel of AGARD, ${ }^{41}$ proposed to apply to NATO the experience of the AGY. NATO should use a launcher built by the US military to put in orbit a satellite with scientific experiences. "It occurred to me", Rechtin recalled,

"that in the US efforts to put up a satellite, the Defence Department was providing just the vehicle and an international organization, the IGY, was really sponsoring the experiments themselves - designing the experiments, and this type of work was done at universities, generally at a very low cost to everyone".

This could easily be replicated, thought Rechtin, in NATO. At another juncture, he reflected likewise:

"I have seen some missiles filled with concrete because they had to have the right weight, otherwise it would not work. Along the same lines, I wonder why the vast stock of obsolete rockets which I know exists could not be made available to other countries". 42

One has to remember that the US military were slowly but surely converting from liquid-fuelled IRBMs, such as the ones developed by the Air Force (Thor) and the Army (Jupiter) to the so-called second generation of missiles, based on solid

40. NATO and Science. An Account of Activities of the NATO Science Committee, 1950-1972, NATO, Brussels, 1973. NATO had already planned an enlargement of its interests to cooperation in the economic, scientific and social fields since 1956, as a way to answer the rising star of détente, see L. SEBESTA, Alleati competitivi. Origini e sviluppo della cooperazione spaziale fra Europa e Stati Uniti, 1957-1973, Laterza, Roma-Bari, 2003, pp.48-50.

41. NATO's Advisory Group for Aeronautical Research and Development set up in 1952 under the aegis of the aeronautical engineer and scientific promoter Theodore von Kármán.

42. Theodore von Kármán Papers, National Air and Space Museum (microfiches, reproduction from the original collection, held at the California Institute of Technology, Pasadena), Washington DC, 35.1, AGARD, Avionics Panel Business Meeting, February 1958, Verbatim extracts of Dr. Rechtin's proposal on satellite research. 
fuel. The first generation, due to the backwardness of atomic weapons technology and, therefore, the substantial weight of nuclear bombs at the time, had to be equipped with boosters that were powerful, but inefficient in terms of operability due to their long ignition time and fixed location. At a time when thermonuclear (and therefore miniaturized and lighter) bombs became available, their thrust came to be considered as seriously over-rated. Rechtin's proposal, therefore, seemed altogether wise from a purely technical point of view.

The idea was endorsed by the US senator Henry "Scoop" Jackson, during the 4th NATO Parliamentarian Conference in November 1958. He proposed as a first goal "a satellite for peaceful outer space research, bearing the emblem of the Atlantic Community and circling the earth by 1960". The idea of Jackson, a notorious hawk, who had suggested the establishing of a "National week of shame and danger" after Sputnik, was considered ill-timed by those policy-makers and scientists whose efforts were focused in keeping publicly satellite-related research out of the Cold War logic. In January 1959, Berkner, from his newly created post of president of the Space Science Board of the National Academy of Sciences, wrote authoritatively that

"to place satellites in orbit under its [NATO] auspices for scientific purposes would tend, in the opinion of the Board, to divide the world into scientific camps based on military considerations. Since the universality of science is an accepted fundamental tenet of the scientific community, the Board feels strongly that the launching of a satellite under NATO auspices would be a real disservice to science and culture". ${ }^{43}$

It would also be a disservice for the American Discoverer programme(alias WS-117L), presented to the public as a scientific endeavour but, as a matter of fact, a cover for three different kind of military-related satellite projects. One of them, Corona, capitalizing on the fact that the Soviet launch of Sputnik had first established a de facto right of space over flight, tried to substitute the highly visible U-2 spy planes with more secure means of reconnaissance by satellite. ${ }^{44}$

European scientists, albeit for different reasons, coincided in opposing any hypothesis of a NATO satellite. Germans for understandable political reasons, were especially eager to avoid any contact with the military, ${ }^{45}$ while some French, so they said, did not want to shut the doors to a possible collaboration with the Soviets. Others, additionally, feared that NATO's activity could be hegemonized by

43. NASA Historical Office, Washington DC, United States, RG 255, 64-A-664, box 1, Berkner to Bronk, 18.01.1959 (the serial numbers refers to the original deposit).

44. The first successful launch of the series Corona took place in August 1960. Discoverer XIV, the name of the first ever recorded reconnaissance satellite, furnished the first of a long series of photographs of Soviet strategic facilities and helped to dismiss the so-called missile gap. Cf. K. RUFFNER (ed.), Corona: America's first Satellite Program, History Staff Centre for the Study of Intelligence, Washington DC, 1995.

45. NASA Historical Office, RG 255, 64-A-664, box 4, Frutkin's Memorandum for the files, Briefing to Senator Jackson's office on NASA cooperative program, 02.12.1959. The Paris Treaty of 1954 had imposed a number of limitations on the development and construction of military systems: among them, no atomic or chemical weapons could be built, no long-range missiles, warships and strategic bombers. 
the energetic Theodore von Kármán, a prospect that met with deep aversion. ${ }^{46}$ Moreover, many were keen to acquire technological expertise on launchers, which would have been discouraged if the US were to give launchers for free. UK scientists, on their part, feared loosing their preferential role with the US. ${ }^{47}$ Last but not least, someone who, like Amaldi, had experienced Soviet strong political reaction at the time of the inception of CERN, definitely disliked the idea of repeating this experience. ${ }^{48}$ The concept of a NATO satellite was therefore eventually dismissed.

\section{Universalism turns to a tacit regime for reconnaissance satellites and scientific space cooperation goes bilateral}

Before the end of the IGY, due to the positive outcome of the experience in scientific terms, it was decided to explore the possibility of continuing the coordination of research activities in outer space. Two avenues were pursued to this end.

In 1958, a Committee on the Peaceful Uses of Outer Space was created in the United Nations to further, as its name suggested, legal discussions on how to guarantee the peaceful nature of future activities carried out in space. At the same time, ICSU set up a temporary Committee of Space Research (COSPAR), with the purpose of developing "further on an international scale the progress of all kinds of scientific investigations which [were] carried out with the use of rockets or rocket-propelled vehicles". The organization, however, as clarified by its founding charter, should "not normally concern itself with such technological problems as propulsion, construction of rockets, guidance and control". ${ }^{49}$ Reflecting the dual nature of ICSU, COSPAR had a mixed membership: representatives of eighteen national academies (or equivalent institutions) and of ten international scientific unions joined the committee. All countries with major programmes in rocketry (Australia, Canada, France, Japan, USSR, UK and the US) were represented. Within this framework, the American delegation officially offered support for projects of mutual interest prepared by scientists of other nations and intended to orbit individual experiments or entire payloads on board of NASA launchers. Projects would be formalized into bilateral agreements, on a no-exchange of funds

46. Archives Armée de l'Air, E 4418, Compte rendu du Comité de recherches spatiales, 20.12.1959.

47. L. SEBESTA, Alleati competitivi..., op.cit., pp.58-61.

48. Together with the other founders, Amaldi had been labelled by the communist press as "war monger" and accused of serving as an American agent, trying to sneak atomic secrets to the Germans; Archivio Amaldi, box 212, Amaldi to Powell, 06.02.1959. See also, R. JUNGK, La grande macchina. I nuovi scienziati atomici, Einaudi, Torino, 1968, p.62.

49. Charter of COSPAR. See Annex 2 of H. MASSEY, M.O. ROBINS, History of British Space Policy, Cambridge University Press, Cambridge, 1986 (p.449 for the citation). 
basis. NASA was also ready to offer resident associate scholarships on its premises in both theoretical and experimental space research. ${ }^{50}$

Reactions to the generous proposal were very positive and, between June and July 1959, first among the European delegations, a British team visited NASA to enquire about the actual possibilities for a collaborative effort, eventually formalized in September 1961, despite the initial reservations of Harrie Massey, head of the British National Committee for Space Research (BNCSR). ${ }^{51}$ The agreement provided for British scientists to define a payload which was eventually carried in a NASA-built satellite (Ariel 1) and launched by an American launcher Thor-Delta, in 1962. Denmark, the Federal Republic of Germany, France, Italy, Norway and Sweden followed soon later. ${ }^{52}$ The Soviets greeted the proposal with a fin de non recevoir; two agreements of modest content were signed in 1962 and 1964. Eventually, John F. Kennedy's offer to explore jointly the moon was left unanswered by the Soviets. Nor did the State Department seem seriously interested in space cooperation with them. ${ }^{53}$

Both countries, however, converged on the usefulness to keep space open and safe for reconnaissance satellites (which were at a very early stage of development), whose stabilizing effect came to be recognized, albeit not publicly, by both. ${ }^{54}$

Negotiations in this area began in the framework of the UN Committee on the Peaceful Uses of Outer Space. After years of spirited debates and negotiations, an agreement on the sanctuarization of space was struck, leading to the signing of the so-called Outer Space Treaty (1967) which still rules activities in space. "The exploration and use of outer space, including the moon and other celestial bodies", its first article reads,

"shall be carried out for the benefit and in the interests of all countries, irrespective of their degree of economic or scientific development, and shall be the province of all mankind". 55

50. NASA Historical Office, RG 255, 64-A-664, box 1, Porter to van de Hulst, 14.03.1959; reproduced in: Ibid., p.462.

51. Massey feared a standardisation on American blueprints and the loss of prestige by his country; PRO, DEFE7/702, "UK participation in research with artificial satellites", statement by Professor Massey, 31.10.1958. See Ibid., pp.455-461.

52. A. FRUTKIN, op.cit.; O. WICKEN, op.cit.; J. STIERNSTEDT, Sweden in Space. Swedish Space Activities, 1959-1972, ESA, Noordwijk, 2001; N. REINKE, German Space Policy, 1923-2002, Brepols, Turnhout forthcoming; L. SEBESTA, Italian space policy between internal renovation and external challenges at the turn of the decade (1957-1963), in M. DE MARIA, L. ORLANDO (eds), op.cit.

53. R. DOEL, International Science in the Cold War: the Politics of US-Soviet Astronomy, 1950-61, in: Bulletin of the American Astronomical Society, 4 (1993).

54. J.L. GADDIS, The evolution of a reconnaissance satellite regime, in: A.L. GEORGE, P.J. FARLEY, A. DALLIN (eds.), US-Soviet Cooperation. Achievments, Failure, Lessons, Oxford University Press, New York-Oxford, 1988, pp.353-372.

55. See United States Arms Control and Disarmament Agency, Arms Control and Disarmament Agreements. Texts and Histories of the Negotiations, US Government Printing Office, Washigton DC, 1990, pp.55-59. 
Fearing the destabilizing effect of putting arms in orbit and unsure on the eventual outcome of such a race, the signatories agreed to limit the uses of space to what became later known as "passive" (or "non-aggressive") military systems, banning weapons from space. Meanwhile, the use of satellites to support military operations would slowly but surely expand from reconnaissance to telecommunication, navigation, early warning, earth observation and targeting.

\section{Getting on its own feet: the origins of ESRO and ELDO}

General references to the need to insert the revival of European sciences into a common frame were aired since the second half of the forties both in UNESCO and within the European movement. ${ }^{56}$ The prospects for a joint effort seemed to be particularly good and needed for that kind of research based on large, sophisticated and costly machines and a critical mass of human resources. All the better if the strands of research to be merged were new and challenging, not yet the reserve of national scientific strongholds. Not by chance, the first efforts towards research cooperation were devoted to the sub-nuclear field. ${ }^{57}$

It is not surprising that two veterans of European cooperation through CERN, Edoardo Amaldi and Pierre Auger, tried, after some years, to repeat the experience in space. During an early spring walk in the Jardins du Luxembourg, 1959, so the story goes, Amaldi shared with his friend and colleague Auger his desire to launch a "euroluna" - a name he had already used in previous correspondence. ${ }^{58}$ Auger, an early promoter of the institutionalization of space research in France, was a perfect ally for the enterprise, and a stronger political player compared to Amaldi: since the very beginning, he had had on his side the Prime minister, Michel Debré, an early-hour space fan, and the minister of Foreign affairs, the influential Maurice Couve de Murville, who had seen in space a possible declination of French leadership abroad. ${ }^{59}$ In view of the first general assembly of the newly created COSPAR, Amaldi wrote a sober six page machine typed document, "Space Research in Europe", first circulated informally among friends and colleagues in English, and thereafter published in French under the more militant title Créons

56. F. PIGLIACELLI, Una comunità europea per la scienza: ..., op. cit. pp.9-38; L. SEBESTA, Alleati competitivi..., op.cit., pp.16-17.

57. On CERN, see A. HERMANN, J. KRIGE, U. MERSITS, D. PESTRE, History of CERN, vol.1, Launching the European Organisation for Nuclear Research, North Holland, Amsterdam, 1987.

58. M. DE MARIA, The inception of the European Space Effort: Edoardo Amaldi and the Euroluna dream, paper presented at the conference on Edoardo Amaldi, Physics, Politics of Research and Civil Commitment, Roma, 20-21.12.1999. See also P. AUGER, The prehistory of ESRO - a personal memoir, in: AAVV, Europe: Two Decades in Space. Recollections by Some of the Principal Pioneers, ESA, Noordwijk, 1984.

59. HAEU, Auger Archives, Box 1, Ministre des Affaires étrangères au Premier ministre, 24.12.1959. See also L. SEBESTA, La science, instrument politique de sécurité nationale? L'espace, la France et l'Europe, 1957-1962 in: Revue d' histoire diplomatique, 4 (1992), pp.313-341. 
une organisation européenne pour la recherche spatiale in $1959 .{ }^{60}$ Many positive reactions were heard from European and American colleagues.

Nobody, except for the cosmic ray physicist, Nobel Prize winner and famous pacifist activist Cecil Frank Powell, raised the question of Soviet membership. More than a Cold War ideological preclusion, there seemed to be, among Western European scientists who had participated to the IGY, a practical anxiety with what had clearly appeared to be during that experience a severe restriction on freedom of speech imposed by the communist regime on their Soviet colleagues. Others, like Amaldi, added to the distrust of the politicization of scientific research in the Soviet Union, the need for pluralism in scientific research and the risks of a merger with such a stronger partner. ${ }^{61}$

A part from Powell, British scientists remained unconvinced by Amaldi's proposal. The reason was not difficult to guess. The British were the most advanced, among Europeans in space-related research and rockets. Thanks to Operation Paperclip, they had familiarized with V-2 technology in early times (firing them in Germany and Great Britain). Researches had been scattered among many laboratories, while the Royal Aircraft Establishment became the main driver behind the national space effort. At the same time, an agreement was signed with Australia to establish a launch facility in Woomera, in the South of the country, where the first Skylark (an off-spring of military rockets research) was launched in February 1957. Since that time, scientists used it as a solid fuelled sounding rocket for upper atmosphere studies. ${ }^{62}$

From a technical point of view, there was therefore no point in the UK joining efforts with the much weaker continental Europeans. This Harrie Massey stated with great clarity and determination in October 1958, at the very moment of the creation of BNCSR ${ }^{63}$ Cooperation with the US, in both the military and civilian field, seemed to offer much greater rewards. As for the former, thanks to US licenses, the UK had been building, as we have seen, since 1954, its own liquid fuelled (IRBM), called Blue Streak. ${ }^{64}$ Money and human resources had been poured into this gigantic effort, which was meant to give the UK autonomy in retaliation in an area stretching from Moscow to the Northern Tier: its range was

60. HAEU, Fiesole, Italy, COPERS-1, Edoardo Amaldi, Space Research in Europe, 30.04.1959, reproduced in N. TINJOD, B. BATTRICK, op.cit., pp.19-24.

61. Archivio Amaldi, box 212, Powell to Amaldi, 02.02 and 06.02.1959; HAEU, Oral interview collection, Jacques Blamont, interview with Lorenza Sebesta, 11.12.1991.

62. The classic account on British space policy is H. MASSEY, M.O. ROBINS, op.cit.; for the beginnings, see also B. HARVEY, op. cit., pp.34-39, N. WHITE, P. GUMMETT, The Military and Early United Kingdom Space Policy, in: Contemporary Record, 2(Autumn 1994), pp.343-369; M. GODWIN, The Skylark Rocket. British Space Science and the European Space Research Organisation, 1957-1972, Brugge, Brepols, 2006.

63. PRO, DEFE7/702, UK participation in research with artificial satellites. Statement by Prof. Massey, 31.10.1958, partially reproduced in H. MASSEY, M.O. ROBINS, op.cit., Annex 3, pp.455-461.

64. The development of Blue Streak went hand in hand with an all-out British effort, Black Knight, to test and solve the delicate problems related to the re-entry vehicle - due to carry the nuclear warhead to the target. See Chr.N. HILL, A Vertical Empire. The History of UK Rocket and Space Programme, 1950-1971, Imperial College Press, London, 2001, p.72. 
over 1,500 nautical miles and it was meant to carry a megaton warhead. Blue Streak was therefore seen as a tool of crucial strategic interest for London, at a time when the newly elected conservative government was seriously beginning to consider the feasibility of the redeployment of British military forces East of Suez. ${ }^{65}$

Concerning civilian cooperation, the British, as seen earlier in the text, also had been the first to start negotiations on space with the US. However, when the COSPAR assembly gathered in Nice in January $1960,{ }^{66}$ they appeared to have developed a new, fresh look into the matter. Massey, the UK delegate, launched the idea of offering British expertise on launchers as the basis of a future European organization devoted to space science: in particular, according to Massey, the common use of a British launcher to launch European scientific satellites could be envisaged in the long term.

The proposal was soon merged with previous Franco-Italian ideas of scientific cooperation in satellites and further discussed in a private meeting held in Paris, at the end of February 1960; Amaldi, Auger, Massey and a few scientists from the Federal Republic of Germany, Belgium, the Netherlands, Sweden and Switzerland attended ${ }^{67}$ In parallel, the British Foreign Office, suggested that

"the UK should take the lead in forming an intergovernmental European space research organization to launch upper atmosphere rockets and orbital satellites, organized along the lines of CERN. [...] The development of Blue Streak as a space research rocket, irrespective of its military applications, will be essential if Europe [was] not to depend on American launching vehicles. Member countries of the projected organization should be invited to share costs". ${ }^{68}$

And so it happened. BNCSR invited European delegations to London in order to formalize the proposals which had emerged in previous months and set up an international committee for the purpose of creating a European organization. On the prestigious premises of the Royal Society, scientists from the above mentioned countries met to discuss the state of space research and single out those experiments that - due to the need of combined tracking and control, or bigger satellites and launchers - could be best conducted in common. Ionospheric studies, meteorology, radioastronomy and aurora borealis, among others, were considered as palatable fields for future cooperation in space. Despite some hesitation, scientists accepted the British idea of combining into a single enterprise the cooperative effort in the field of artificial satellites and that of a future, jointly developed and financed, launcher. ${ }^{69}$

65. S. DOCKRILL, Britain's retreat from east of Suez: the choice between Europe and the world?, Palgrave MacMillan, Basingstoke, 2002.

66. A parallel international symposium on space reunited in Nice scientists from Belgium, France, Great Britain, Italy, the Netherlands, the Federal Republic of Germany, Sweden and Switzerland.

67. The Norwegian scientist Svein Rosseland was also invited, but could not join the meeting. See H. MASSEY, M.O.ROBINS, op.cit., p.110.

68. PRO, DEFE 7/702, International co-operation in space research. Draft prepared by the Foreign Office for consideration by the Steering Group on Space Research, Annex (secret), 15.02.1960. The Steering Group on Space Research had been created in the Spring of 1959 by the ministry of Science "to assist supervising the space research program as a whole".

69. Archivio Amaldi, box 248, Western European Space Research Meeting, 29 April 1960, Minutes and Resolutions. 


\section{A "valuable card". Blue Streak in the context of a European nuclear trusteeship}

In order to appreciate British interventionism in the matter, and France's complacent attitude, one has to set aside the field of scientific research for a moment and look carefully into hard politics in the field of missiles at the time.

Let's start with Great Britain. Blue Streak had been, since the beginning, a controversial enterprise. Some very good reasons converged against this extremely ambitious and expensive arms system, in a time of agonizing reappraisal of a military budget which many considered too ambitious in terms of $R \& D$ and innovative projects. ${ }^{70}$ Nor was its fortune improved by the March 1957 agreement with the US, by which the UK had accepted to host US Thors on its soil. ${ }^{71}$ Thors, albeit less powerful in terms of range, were similar to Blue Streak as far as technical features were concerned. This US offer would be enriched, in March 1960, by the promise to furnish the air-to-air Skybolt missile, which could be used by British V-bombers (of the series Vulcan) - less detectable by foreign early warning systems and more rapid in their response compared to conventional bombers.

Blue Streak had been also under severe scrutiny by those preoccupied by the security concerns linked to the underground silos where the missile and its highly inflammable liquid fuel would be stored. Last but not least, Blue Streak had been opposed not only by the Army and the Navy, but, what was worst, by a substantial part of the Air Force - inclined to grant a much deeper attachment to the traditional symbols of British excellence and superiority, the bombers. Despite all this, Macmillan, in his memories, makes reference to his own anxiety vis-à-vis the perspective to throw away the 60 million pounds sterling already spent on a project which would need 500 million more to enter into the operational phase (with silos and nuclear warheads). ${ }^{72}$

What about France? Pondering the status of the force de frappe in March 1960, the Etat-Major général des Armées stated that "malgré les brillantes promesses faites au gouvernement français par le gouvernement américain au cours des années 1957-1958", nothing had been obtained for France's own missile force. "Du côté anglais, on s'est refusé de discuter une coopération sur l'engin balistique stratégique", due to the existing treaties with the US. ${ }^{73}$ What to do next? The

70. T. GEIGER, The Next War Is Bound to Come: Defence Production Policy, Supply Departments and Defence Contractors in Britain, 1945-57, in: A. GORST, L. JOHNMAN, W.S. LUCAS (eds.), Contemporary British History, 1931-61: Politics and the Limits of Policy, Pinter, London, 1991, pp.95-118.

71. Formalized in 1958, this agreement gave its results in June 1959, when the first squadron of US IRBM were earmarked to the Royal Air Force; M NEVIAS, Nuclear Weapons and British Strategic Planning, 1955-58, Clarendon Press, Oxford, 1991, p.147; J. MELISSEN, op.cit.

72. H. MACMILLAN, Pointing the Way: 1959-1961, Macmillan, London, 1972, pp.251-252.

73. Archives Armée de l'Air, E 1777, Comité de défense restreint, 11.03.1960, Annexe I, Fiche établie par l'Etat-Major général des Armées sur la force de frappe nationale. 
Comité de Défense, the highest military decision body, in a restricted meeting of the same month, stressed that, despite the priority attributed to the resolution of the Algeria question,

"nous devons quand même, sur le plan technique, entreprendre des études dont les développements permettent, non seulement de réaliser nos engins stratégiques, mais aussi de participer à la conquête de l'espace. [...] Le système de propulsion devrait être capable d'engager la voie sur la conquête de l'espace dont les satellites constituent dans un avenir difficile à préciser un élément militaire essentiel".

Everybody agreed that the technical difficulties involved in missiles were greater that those involved in the development of atomic bombs. ${ }^{74}$ The delicate choice between liquid and solid propulsion, which brought the Army, with its Laboratoire de Recherches Balistiques et Aérodynamiques (LRBA) of Vernon, into opposition with the Direction technique et industrielle de l'Aéronautique (DTIA) drawing on the private Société pour l'étude et la realisation d'engins balistiques (SEREB) (which had been focused, since the beginning, on solid fuel techniques), had not been settled yet. ${ }^{75}$

It is not unfair to believe that during 1960 and the first part of 1961, therefore, despite what some actors from the technical and military fields have asserted, ${ }^{76}$ no avenue for missile development was being light-heartedly discarded - all the more so if it fitted with the political vision of General de Gaulle and his Defence minister Pierre Messmer, who considered the force de frappe, first and foremost, as a political device to sit at the table with the big powers. ${ }^{77}$

If this was true, couldn't France's accession to the nuclear club be a prelude to a revamped UK-French collaboration on advanced weapons? Could the Sahara test of February 1960 be considered that "substantial knowledge" required in the new version of the MacMahon Act in order to make technology sharing possible? ${ }^{78}$

In parallel with the meeting of the Comité de Défense, and few weeks after the first French atomic test, the British Prime minister began to unfold his new strategy vis-à-vis France. The UK was strong in the nuclear field, he said in a meeting with

74. Ibid., Comité de défense restreint, Extrait des décisions, 11.03.1960.

75. Armée de l'Air, E 4418, Procès-verbal des 17e et 18e session du Comité des recherhces spatiales, 24.05 et 24.07.1960, Annexe I, Déclaration du représentant de l'Armée de l'Air, 24.05.1960.

76. M. VAÏSSE (ed.), L'essor de la politique spatiale française dans le contexte internationale, 1958-1964, Ed. des archives contemporaines, Amsterdam, 1997, pp.103-107. The text refers to the debate born out of John Kriges' intervention at a seminar held in Paris, 1995, where he had alluded to a possible exchange of technology being the reason of France's acceptance of Blue Streak as the basis for a European launcher organization.

77. D. PESTRE, Innovation technique, fonctionnement des institutions et politique: créer la Délégation ministérielle pour l'Armement et concevoir les missiles de la force de frappe française, in M. VAÏSSE (ed.), Armement et Ve République, fin des années 1950-fin des années 1960, CNRS, Paris, 2002, pp.5-12.

78. As a matter of fact, the French thought at first that the Sahara explosion could open the avenue for a direct Franco-American collaboration in this field. They would soon be disillusioned: M. VAÏSSE, La politique française à l' égard de l'OTAN (1956-1958). Continuité ou rupture?, in: La Documentation Française, De Gaulle en son siècle, vol.IV, La sécurité et l'indépendance de la France, Plon, Paris, 1992, pp.71-86, spec. pp.79-81. 
de Gaulle in March 1960. "Elle avait aussi entreprise la construction d'engins, mais au prix d'efforts coûteux". In ten years, Macmillan presumed, strategic bombers would be outdated. "Ne vaudrait-it pas mieux", he said according to French minutes, "mettre en commun les efforts des deux pays pour aboutir à des réalisations conjuguées"? Americans ("de bons garçons" according to Macmillan) should be appeased with European charm and amicable contacts. There was no need nor convenience in antagonizing them, the British Prime minister suggested. De Gaulle's idea of a triumvirate could be indeed revamped, albeit reshaped in a more informal way. To this de Gaulle answered that "l'idée d'une conjugaison des efforts de la France et de la Grande Bretagne n'appelait non plus aucune objection de sa part". ${ }^{79}$

It should not be surprising, therefore, that, during Easter time, when Duncan Sandys, minister of Defence at the time of the inception of Blue Streak (now in charge of the newly created ministry of Aviation, the government's largest R\&D spending agency at the time), visited Paris to discreetly inquire about the possibility to transform Blue Streak into a common civilian enterprise, he received quite a positive answer. He was also welcome, albeit for different reasons, in Bonn. ${ }^{80}$

In the summer of 1960, Macmillan's closest aides furthered their plans for a sort of "nuclear trusteeship" for NATO. Frederick Bishop was the most audacious, even recommending a common control on UK and French nuclear capabilities, which could become "'trustees' for European members of NATO". Bishop knew that many in the Foreign Office, traditionally prone to a strict pro-American stance, would not be pleased and that this perspective would be seen by the military as "horrifying". However, he thought it was worth a try. Blue Streak was definitely a card to play in this context. It was highly possible, according to Bishop, to convince France to participate to a common satellite launcher, building on its "interest in missiles in general". The Americans, which stood in the way as the only obstacle to this arrangement,

"might even welcome an Anglo/French space research programme based on the joint development of Blue Streak, as part of some general agreement to meet French ambitions on the missile and nuclear field".

At the same time, Bishop suggested a deepening of relationships with the Common Market, which should not take the form of a formal request of membership but, rather, of a "political infiltration" coupled with a drive towards the creation of a free trade area between EEC and EFTA. ${ }^{81}$ The idea of a sort of grand bargain between help to France in the field of advanced weapons and a British drive

79. Ministère des Affaires étrangères (MAE), Archives diplomatiques, France, Secrétariat général (1945-68), vol.10, Entretien du général de Gaulle et Monsieur Macmillan, 13.3.1960.

80. PRO, CAB 134/1428, Memorandum by the ministry of Aviation, B.S. (60)2, 28 November 1960. The document summarizes UK approaches to Europe on Blue Streak.

81. PRO, PREM 11/2983, Memorandum Bishop for Prime minister, "Joanna Southcott's Box", 8 July 1960 (secret and personal). This document and a related one by Macmillan were analyzed with humour and philological accuracy in A. PAGEDAS, op.cit., pp.113-114. 
towards the Common Market (or, better, a Common Market drive towards the British vision) was at the time discussed in inner British circles. This idea, which surfaced from documents by Pierson Dixon (ambassador to Paris from October 1960) and Norman Brook (the influential secretary of the cabinet) ${ }^{82}$ has been more than once explored in relation to its nuclear content. ${ }^{83}$

As it has been suggested by Constantine Pagedas, Blue Streak (and the technology it embodied) appeared to be seen for a while by the British as a bargaining chip within this dangerous game, i.e. as an entry fee into the Common Market and, at the same time, as a way to reinforce the European nuclear component in NATO. ${ }^{84}$ Indeed, as Bishops realized in July 1960, "the most obscure factor [was] whether the Blue Streak would provide [the UK] with a valuable card in our relations with European countries - particularly the French". ${ }^{85}$ In other words, would technological help in the missile field be enough to strike a deal?

\section{De Gaulle's “imposante confédération”}

The ideas discussed in restricted British circles were not so far from those being elaborated by de Gaulle at the very same time. The "Europe" the General was beginning to conceive would encompass "l'action, le progrès et la défense", and hopefully evolve, in a not too distant future, in "une imposante confédération". In the General's jargon, this word referred to a group of states, with no "virtualité fédérale", which seemed to be not very far from the British concept of loose federation. ${ }^{86}$ At the same time, on the verge of completing the first stage of the European customs union (31 December 1960) de Gaulle was eager to appease British fears. "Sans doute" he said

"les participants ne veulent-ils pas que cette institution puisse blesser les autres pays d'Europe, et l'on doit compter qu'un accommodement sera trouvé entre les intérêts". 87

Talking with Chancellor Konrad Adenauer in July 1960, the general suggested

"qu'il faut mettre sur pied une organisation européenne qui dise quelque chose aux peuples et dans laquelle ces derniers se sentent responsables de leur propre défense.

Tel n'est pas le cas de l'OTAN qui chaque jour devient plus artificielle".

Neither had the Commission and its "fonctionnaires apatrides" a better reputation in the general's eyes. The European organization suggested by de

82. L. SEBESTA, Alleati competitive ..., op.cit., pp.116-117.

83. See, for example, W. KAISER, The Bomb and Europe. Britain, France and the EEC entry negotiations (1961-1963), in: Journal of European Integration History, 1(1995), pp.65-85.

84. A. PAGEDAS, op.cit., p.124.

85. PRO, PREM 11/3098, Bishop to McMillan, 05.07.1960.

86. A. PEYREFITTE, C'était de Gaulle, vol.I, La France redevient la France, Fayard, Paris, 1994, pp. 67 et 70 .

87. Allocution radiotélévisée du général de Gaulle, 31.05.1960. See web site Franceurope. 
Gaulle, to be accomplished in the "domaines politique, économique, culturel et dans celui de la défense", was to be intergovernmental and stand united vis-à-vis the US. ${ }^{88}$

De Gaulle was thinking along the lines of a traité de commerce for the future of European integration, coupled with political cooperation at high level. In February 1961, a European working group chaired by Christian Fouchet, French ambassador to Denmark and loyal Gaullist, was created to discuss this plan. The Fouchet Plan would soon be launched and discussed among the members of the European Communities. ${ }^{89}$ This could indeed have pleased the British, but a big incognita stood in the way, as the pillar of this plan was not, in de Gaulle's eyes, a Franco-British nuclear agreement, but rather a Franco-German political deal. ${ }^{90}$ This obviously contrasted with Macmillan's vision.

Moreover, De Gaulle saw in Europe not only a way to re-invent French grandeur, but also the only possibility to flee the unpleasant choice between becoming Russian colonies or American protectorates. ${ }^{91}$ Macmillan was definitely less sanguine on the point, not to mention the Foreign Office, which held a very definite pro-American orientation.

\section{A reality and a gamble: ESRO and ELDO come to life}

Between the 28th of November and the 1st of December 1960, on the premises of CERN in Geneva, scientists from Belgium, Denmark, Germany, France, Great Britain, Italy, the Netherlands, Norway, Spain, Sweden and Switzerland discussed the future of European collaboration in space. Gone were the times of ideal visions. Time had come for bargains to be struck related to the sharing out of costs, to the site of establishments and, eventually, to the way scientific research would be performed within the organization. Scientists wisely decided to keep the discussion on the launcher separate and go on with their own affairs. On the other hand, they set up a preparatory group (COPERS) which duly collected a dream catalogue for space research, the so-called Blue Book, where a vast series of short, medium and long-term projects with experiments in lower and upper atmosphere and astronomical studies was proposed. The launch of a total of 435 sounding rockets and 17 satellites was forecast within a period of eight years. The future organization would stick to integrating the national experiments in common

88. MAE, Secrétariat général (1945-68), Entretiens et messages, vol.12, Entretien de Gaulle-Adenauer, Rambouillet 29-30/7/1960.

89. G.-H. SOUTOU, Le général de Gaulle et le Plan Fouchet, in: AAVV, De Gaulle en son siècle, vol.V, L'Europe, Plon, Paris, 1992, pp.126-143.

90. This is very clearly stated, for example, in a note to Michel Debré, in: Charles de Gaulle, Lettres, Notes et Cahiers, janvier 1961-1963, Plon, Paris, 1986, p.49. In general, see G.-H. SOUTOU, L'alliance incertaine ..., op.cit.

91. A. PEYREFITTE, C'était de Gaulle, op.cit., vol.I, p.62. 
payloads and to manage the phases of launch, tracking, telemetry and gathering of data. $^{92}$

At the same time, negotiations on the "Europeanisation" of Blue Streak entered a crucial phase. When confronted with the necessity to formalize its support for Blue Streak as the future European launcher for scientific satellites, the French government began consultation with its scientists, engineers and military. Only to find negative reactions. Scientists feared that, due to the anticipated limitation in budget, money for the launcher would be deducted from that potentially devoted to science. Engineers and the military were not attracted by what many of them considered as an obsolete technology - more so if, as general Robert Aubinière, they belonged to a military service which had constantly favoured the solid fuel technique, against the liquid-fuel one sponsored by the Army. ${ }^{93}$ The Defence minister Pierre Messmer and François de Rose, the head of the Service des Pactes et des Affaires atomiques et spatiales of Quai d'Orsay, however, were more flexible and insisted that, if the UK could grant concessions in terms of guiding system and re-entry vehicle, they would be able to guarantee the support of general de Gaulle to the Europeanisation of Blue Streak. ${ }^{94}$

At the end of 1960, US security strategy for Europe finally coalesced around the idea of a Multilateral Force (MLF), equipped with American Polaris missiles to be installed on American submarines with multinational fleets, under SACEUR's command. ${ }^{95}$ Efforts towards the construction by Europe of "modern weapons including IRBMs" (as forecast by NATO in December 1957) were abandoned altogether as the favourite American strategy. In this context, previous discussions with his closest aids and the prospective change of US presidency persuaded Macmillan to conceive a grandiose plan for a redirection of UK external policy and of NATO's course of action. Half jokingly defined as his own "Grand Design", the plan was carefully drafted between the end of 1960 and the first days of the new year. Again, the idea of nuclear collaboration with France re-emerged as a central concept. Could France and Great Britain become "the nuclear trustees for NATO"an expression first used by Bishop, as we have seen? ${ }^{96}$ This strategy could, in one shot, stop the nationalistic bent of de Gaulle's policy, offer a palatable alternative to

92. J. KRIGE, A. RUSSO, A history of European Space Agency, 1958-1987, vol.I, The story of ESRO and ELDO, 1958-1973, ESA, Noordwijk, 2000, pp.34-67.

93. O. HUWART, Missiles et lanceurs spatiaux: la France gaullienne relève le défi technologique et politique (1958-1964), in: M. VAÏSSE (éd.), Armement et Ve République ..., op.cit., pp.375-391.

94. PRO, PREM 11/3513, From Paris to Foreign Office, 24.12.1960 (secret). See also J. KRIGE, Le choix européen, in; M. VAÏSSE (éd.), L'essor de la politique spatiale française ..., op.cit., p.98.

95. M. GALA, The Multilateral Force: A Brief History of the American Efforts to Maintain the Nuclear status quo within the Atlantic Alliance, in: Storia delle relazioni internazionali, 1(1998), pp.121-149, spec. pp.135-137. For a different interpretation, see M. TRACHTENBERG, A Constructed Peace. The Making of the European Settlement, 1945-1963, Princeton University Press, Princeton, 1999, pp.213-214.

96. PRO, PREM 11/3325, Memorandum by Prime minister, 29.12.1960-03.01.1961. On the document and the circumstances surrounding it, see A. HORNE, op.cit., pp.284-286. 
the consolidation of US hegemony within NATO and reinvigorate the Western world vis-à-vis Russian scoops.

De Gaulle and Macmillan, meeting in Rambouillet at the end of January 1961, exchanged polite words on British desire to enter the EEC (which, in the words of de Gaulle, was "nullement destiné à exclure la Grande-Bretagne") ${ }^{97}$ and on the French desire to access to the US and GB status as great powers at all effects. Macmillan talked about his idea of a tripartite nuclear trusteeship within NATO, which should involve the UK, the US and France. According to British minutes, de Gaulle was keen to see Europe become the third space power in the world. French minutes do not make any reference to this, but Francois de Rose, the éminence grise of French international cooperation in nuclear and space matters and prime mover of de Gaulle's acceptance of Blue Streak as the basis of European space cooperation, ${ }^{98}$ opening a diplomatic conference on the topic in Strasbourg a few days later, used the very same expression. ELDO, he said in Strasbourg, would make Europe "la troisième puissance spatiale du monde". ${ }^{99}$

During this meeting, discussions on the structure of a future launcher (a three-stage liquid fuelled vehicle) and share of costs began. The most important results in British eyes, however, was the full support obtained from the French government for the idea of a European organisation for building civilian launchers based on the technology developed for Blue Streak. Apparently, before Strasbourg, de Rose had obtained from Peter Thorneycroft, who had succeeded Duncan Sandys as British minister of Aviation, the moral commitment to raise the question of the passage of technical information on missiles to France with the US as soon as possible. ${ }^{100}$ As for the other most eminent participants, Germany and Italy, their reaction was reserved. Not only did some scientists fear that the expenditures for the launcher would compromise their own field of interest but, more importantly, everyone seemed to be waiting for a green light from the Americans. ${ }^{101}$

The green light was duly obtained, albeit in a very anodyne form, some time later, when the US administration informed the Foreign Office that it would not object to the project unless France reiterated its requests for military information. ${ }^{102}$ While Germany, to which the construction of the third stage had been offered during the Summer (the second would be provided by France), decided to participate, thanks to the decisive favourable position of the ministry of

97. MAE, Entretiens et messages, 1958-1968, vol.13, Entretien de Gaulle-Macmillan, Rambouillet, 28.01.1961.

98. "De Rose expressed himself all for co-operation and recognized that there was an immense amount of duplication at the present moment. As an illustration of his attitude, he cited Blue Streak and told me that it was he who had persuaded General de Gaulle that France should join us. It turned out, too, that de Rose had seen Mr. Thornecroft on more than one occasion". PRO, PREM 11/3712, Zuckerman to Prime minister (secret), 25.05.1962.

99. See L. SEBESTA, Alleati competitive ..., op.cit., p.122.

100. PRO, PREM 11/3513, Strasbourg to Foreign Office, 30.01 .1961 (secret).

101. PRO, FO 371/157349, Bonn to Foreign Office, 01.05.1961 (secret).

102. PRO, FO 371/157342, Minutes H.C. Hainworth, 27.02.1961 (secret). 
Foreign affairs, the Italian delegation, reflecting the instability of its governments and, maybe, some US pressure, remained undecided till the end of the year.

During the conference of Lancaster House, in London, held from the 30th of October to the 3rd of November 1961, the countries agreed on the share of work, with Britain, France and Germany having been attributed the three stages of the launcher, Italy the satellite, Belgium the ground guidance and the Netherlands the telemetry system. Italy, however, was unable to sign up to any formal participation. The signature of the agreement, therefore, had to be postponed until spring 1962, when the Italian position was finally reversed. ${ }^{103}$

\section{The shadow history of ELDO}

During 1961, the British, from time to time, raised with the Americans the question of sharing advanced techniques with their European partners, receiving contrasting messages, depending on the person approached. In particular, while some well-known friends of Europe seemed to be keen to indulge in generosity, other officials were definitely more reserved. For example, McGeorge Bundy, at the time special assistant to the president for nuclear affairs, talking with UK ambassador Harold Caccia, said on April 22nd 1961 "(...)for our secret information that the president was reconsidering the French desire for nuclear weapons and launcher development know-how". "The nuclear aspect", continued Bundy, "was by far the most difficult, since any change in the present position would need congressional approval. The rub here was that as contrasted with launcher systems, there was good evidence that the United States had reached a higher degree of sophistication than that of the USSR and that, rightly or wrongly, the Congress was firmly convinced that French nuclear scientists were deeply penetrated by the Communists". "In contrast to this", continued Bundy,

\footnotetext{
"there was no legislative prohibition about imparting information on launching systems and it would at present be 'quaint' to suggest that even if the French were penetrated, they could pass on anything in many types of rocketry to the Communists of which the Russians were not already full aware".
}

Indeed, apart from a juvenile flair for Trotskyism of general Robert Aubinière, more linked to his dashing character than to his ideological affiliations, ${ }^{104}$ it would be rather hard to find any clue of communist affiliation among the first French space fans. According to McBundy, other more important problems had to be solved like, for example, what to do with Germany if the country ever demanded "an unfettered right to know-how and construction". However, he said, there

103. J. KRIGE, A. RUSSO, A history ..., op.cit, pp.91-98.

104. HAEU, Oral Collection, Interview Robert Aubinière with L. Sebesta, 17.12.1991. On the personality and life of general Aubinière, see Propos en forme de mémoires du général Robert Aubinière, un des pères de la conquête spatiale française, recueillis par André Lebeau, L'Harmattan, Paris, a paraître. 
seemed to stand an interesting possibility to overcome the long-standing impasse. ${ }^{105}$

During Macmillan's first visit to Kennedy, the US president, according to British minutes, "felt that it might be possible to give French some military information about a missile and aircraft". When the draft minutes returned to the UK after a US check, the word "missile" was missing. Kennedy also suggested that this information (on aircraft and/or missile, depending on the version of the minutes) could be given to France "perhaps in connection with a European space project" ${ }^{106}$ This would be "more politic" [sic], Kennedy would say, in order to refrain from being accused of proliferation and indirectly legitimise possible Soviet help to China in this field. ${ }^{107}$ There are good reasons to think that Kennedy's allusion, on the verge of a British formal request to enter the European Economic Community (July 1961), could have reinforced Macmillan's optimism on the possibilities of obtaining America's support for sharing technology with French, at least in the field of missiles. The French, apparently, were aware that the American position was less stringent in this field than in the more controversial atomic one. ${ }^{108}$ This support, it is important to stress, would reverse a well established NSC policy, opposing any French "formal requests to the US for an IRBM program". 109

Was space the medium through which Macmillan's "Grand Design" and De Gaulle's "imposante confédération" could converge? Philip de Zulueta, private secretary and among the most listened to of Macmillan's closest collaborators, was ready to bet on this. Referring about the ministry of Defence agreement on "your ideas about nuclear weapons and France", he suggested to Macmillan that, "any effective Anglo-French arrangement which would have a chance of achieving the satisfactory results envisaged by the minister of Defence" should involve giving the French thermonuclear weapons (best if manufactured in the UK, without providing any technical information), and "reaching agreement with the French on a joint Anglo-French study designed to lead to an effective delivery system for nuclear weapons in the 1970s. Such venture might well be", de Zulueta added, "a European one based perhaps on a development of ELDO". Once the reality of the agreement had been accepted, it would with no doubt be possible "to find suitable ways of fitting it nominally into the NATO pattern". ${ }^{110}$

Apparently, the question of military information related to Blue Streak was never raised again by the French, except from an informal talk between François de

105. PRO, FO 371/157349, From Washignton (Caccia) to Foreign Office, 22.04 .1961 (top secret).

106. The fact that this part was not deleted by the US seems to confirm the accuracy of the original version of the minutes.

107. FO 371/157352, Minute of Douglas Hurd, visit PM to Kennedy, 08.06.1961 (top secret).

108. M. VAÏSSE, La grandeur ..., op.cit., p.213. For a more general overview of US-France relations in the field of missiles, see L. SEBESTA, Les rapports franco-américains dans le domaine des vecteurs au début des années 1960, in: M. VAÏSSE (éd.), Armement et Ve République ..., op.cit., pp.347-373.

109. FRUS 1955-1957, vol.XXVII, NSC 5721/1, US Policy on France, 19.10.1957, p.189 and p.192.

110. PRO, PREM 11/3712, Memorandum Philip de Zulueta, 13.04.1962. 
Rose and Solly Zuckerman ${ }^{111}$ at the end of May 1962, when the first asked whether there would be any possibility to "get together to work on a strategic delivery system". ${ }^{112}$ However, in spring 1962, when an attempt in extremis to stop the incipient signature of ELDO was made by General Aubinière, then director general of the newly born CNES, with the then Ministre d'Etat délégué pour la Recherche Scientifique, Pierre Guillaumat, de Gaulle reacted with a handwritten note that, according to Aubinière, read more or less:

"Nous sommes engagés, nous signerons la convention ELDO et si d'aventure les Anglais venaient à manquer à leurs engagements, nous ne ferons que dénoncer la convention". ${ }^{113}$

\section{The window of opportunity shuts}

Which engagements de Gaulle was referring to? The time of truth was soon approaching. When the Fouchet Plan was rejected in April 1962, NATO seemed to have reassured its centrality in the defence of Europe. Moreover, the adoption of the US strategic doctrine of the "flexible response" by NATO, centred as it was on the necessity to graduate its response and tune it to the nature of the offence received, placed an even bigger premium than before on the centralization of command and decision. In this context, the American decision to withdraw the offer of Skybolts to the British represented a great challenge to Macmillan's "Grand Design", as it deprived the country of its independent nuclear deterrence. Under the urgency of a choice for the replacement of Skybolt, any hypothesis of a "Anglo-French co-operation in the building of delivery vehicles in the post-bomber era" seemed, to many, superfluous. Maybe, in a far distant future, and surely after UK accession to the EEC had been secured, talks could be revamped. At present, however, the usefulness of such a move was very doubtful. ${ }^{114}$

Pierre Messmer, then French minister of Defence, giving his version of the sudden British aloofness on the topic of UK-Franco cooperation on missiles, hints at the possibility of a personal intervention by president Kennedy as being the reason for the sudden rejection of an agreement that, according to him, had been

111. Zoologist and political adviser, he was scientific adviser at Combined Operations HQ from 1939 to 1946 and chief scientific adviser to the British government from 1964 to 1971.

112. PRO, PREM 11/3712, Memorandum Zuckerman to Prime minister, 25.05.1962.

113. M. BIGNIER, Débat, in: M. VAÏSSE (éd.), L'essor de la politique spatiale ..., op.cit., p.106. Bignier makes reference to an oral testimony of general Aubinière, who saw the manuscript note of the general. The text in the cited book contains a misprint, which has been corrected here by the author.

114. PRO, PREM 11/3712, Memorandum De Zulueta (top secret), 07.12.1962. De Zuelueta was reporting a meeting among Burke Trend, Harold Caccia, Robert Scott and Roger Makins. 
already agreed on. ${ }^{115}$ This is indeed an interesting remark, which seems to reinforce the hypothesis of a change of mind of Macmillan at the end of 1962, allusively transmitted to de Gaulle in Rambouillet, where he and the General met again in December 1962.

In Rambouillet, according to British minutes, Macmillan informed de Gaulle of the necessity to look for an "adequate replacement" for Skybolt. ${ }^{116}$ On the same day, according to French minutes, and, plausibly, after Macmillan's remark, de Gaulle stated "sans doute, devra-t-on réfléchir aux possibilités de faire quelque chose de franco-britannique, par exemple dans le domaine des fusées". In the final summing up, the general was even more explicit, in contrast to his tradition. French minutes report that

"l'éventualité d'une construction en commun, par la France et la Grande Bretagne, des moyens de transporter des bombes, fusées, etc., a été évoquée. La France, pour sa part, serait tout disposée à collaborer dans ce domaine avec la Grande Bretagne, comme elle l'a fait pour Blue Streak, ou pour l'aviation supersonique". 117

French and British minutes do not offer any hint about Macmillan's reaction, but a subsequent British document on the same issue clarifies that the Prime minister "made no comment on this idea". 118

While de Gaulle had duly signed ELDO, the British were now declining to remember the price attached to it - maybe the famous "engagements" referred to by de Gaulle at the time of ELDO's signature. ${ }^{119}$ It didn't take too much time for de Gaulle to make up his mind as far as the retaliation to be taken, the more so as it fitted with the results of the ongoing economic negotiations on the British access to the EEC. ${ }^{120}$ De Gaulle's veto to British entrance in the EEC has been more than once analysed and we will refrain from doing so once again. The same goes for the subsequent agreement with Adenauer, which stood as a symbol of the primacy de Gaulle attributed to political relationship with the Germans. Indeed, the disappointing story of Franco-British contacts on missiles reinforced de Gaulle's original perception of the Federal Republic of Germany as being pivotal in any

115. P. MESSMER, De Gaulle's defense policy and the United States from 1958 to 1969, in: R. PAXTON, N. WAHL, De Gaulle and the United States. A Centennial Reapprisal, Berg, Oxford, 1994, p.354.

116. PRO, PREM 11/4147, Record of a meeting at the chateau of Rambouillet (top secret), 16.12.1962. For some of the interpretations given of this meeting by different historians and journalist, see L. SEBESTA, Alleati competitive ..., op.cit., pp.138-139.

117. DDF, 1962, vol.II, doc.200, Compte rendu d'un entretien de Gaulle-Macmillan, 15-16.12.1962, p.545 and p.550. A Franco-British agreement for the construction of the future Concorde had been signed in November of the same year.

118. PRO, PREM 11/4147, Memorandum from Paris (P. Dixon) to the Foreign Office (top secret), 01.01.1963.

119. Many primary sources indicate that the British would be ready to offer nuclear help after their entrance in the European Communities - and not before. But this should be the object of yet another article ....

120. A.S. MILWARD, The United Kingdom and the European Communities, vol.I, The Rise and Fall of a national strategy, 1945-1963, Frank Cass, London, 2002. 
security strategy for France. It is maybe interesting, for the sake of our own little story, to notice that de Gaulle, talking with Adenauer on the verge of the signature of Elysée Treaty, hinted at the possibility to build common space launchers, which "évidemment, un jour [...] pourront servir à autre chose". ${ }^{121}$

The window of opportunity definitely closed with the accession to power in Britain of the Labour in 1964. Harold Wilson, the new Prime minister, shadow Foreign Secretary at the time of the birth of ELDO, had strongly opposed any attempt to keep an independent nuclear deterrent for the country. The technological revolution he and the Labours embraced was set to redeploy investments in R\&D from missiles and warheads towards the production of new tools for economic advance in Britain and for war against poverty in under-developed countries. ${ }^{122}$ Indeed, ELDO would be twice torpedoed by Wilson, in 1966 and 1968, while de Gaulle, despite all, would keep faith in his early engagement. He maybe regretted this choice, ${ }^{123}$ but never bounced back.

Here is one of the plausible versions of how and why European space came to life. Many visionaries were behind it, the scientists not being necessarily the most audacious among them. The failure of some original ideas behind the European space adventure does not mean that those ideas were not there and had no impact on the outcome of the negotiations. These ideas, highly secretive, were decisive on the internal front both in France and in Great Britain even if they turned out to be impracticable, partly as a result of ambivalent American behaviour on non-proliferation policy and partly as a result of British reluctance to abandon a well-established pattern of foreign relations. Space cooperation, seen in this light, seems to acquire a new meaning. It is not only the result of scientists' talks and dreams, nor only a way to legitimize their work, and overcome the financial and moral dilemmas they faced at the end of World War II. More intriguingly, it seems to be the outcome of an aborted change of paradigm within Euro-Atlantic relations, and it helps to reflect on some of its most long-lasting contradictions.

121. The meeting was held on 21.01.1963 and the sentence is cited in M. VAÏSSE, La grandeur ..., op.cit., p.256.

122. D. EDGERTON, The "White Heat" Revisited: The British Government and Technology in the 1960s, in: L. GUZZETTI (ed.), Science and Power. The historical foundations of research policies in Europe, European Commission, Brussels, 2000, pp.207-236, spec. p.212

123. To Peyrefitte, at two different times (in May 1962 and, again, in 1964) the general said it had been a "faiblesse" of his own, justified by the fact that he saw Macmillan so desperate by the idea of being rejected from the Common Market; A. PEYREFITTE, op.cit., vol.1, p.151 and vol.3, p.128. In spring 1962, at the time of ELDO's signature, however, the fate of the British demand of accession to the EEC was all but decided. 
